\title{
SIMULATION OF DEPOSITION THE CORROSION WASTE IN A WATER DISTRIBUTION SYSTEM
}

\author{
Ivana JELENÍKOVÁ', Ondřej ŠIKULA, Jana PERÁČKOVÁ
}

\begin{abstract}
In water distribution systems can be found particles of rust and other mechanical contaminants. The particles are deposited in locations where the low velocity of water flow. Where a can cause the pitting corrosion. Is a concern in the systems made of galvanized steel pipes. The contribution deals with CFD (Computational Fluid Dynamics) simulations of water flow and particles deposition in water distribution system. CFD Simulations were compared with the corrosive deposits in real pipeline. Corrosion is a spontaneous process of destruction of metal material due to electrochemical reactions of metal with the aggressive surrounding. Electrochemical corrosion is caused by the thermodynamic instability of metal and therefore can not be completely suppress, it can only influence the speed of corrosion. The requirement is to keep metal properties during the whole its lifetime. Requested service lifetime the water pipe according to EN 806-2 is 50 years.
\end{abstract}

\section{INTRODUCTION}

Particles of rust and other mechanical contaminants can be found in water distribution systems. The particles are deposited in segments with low velocity of the water flow and can cause a pitting corrosion. Mainly systems made of galvanized steel pipes are concerned. The contribution deals with Computational Fluid Dynamics (CFD) simulations of water flow and particles deposition in a water distribution system.

Electrochemical reactions occur at phase interface electrode - electrolyte. Two electrodes are required for the electric current to pass between the electrolyte and the electrode, forming an electrochemical cell. The electrode can be any solid or liquid phase, which is electron or ion conductive. Metals with different electric potentials form the electrochemical cell, which is a prerequisite for the electrochemical corrosion. Metals with different electrochemical potentials are often connected in the piping, which leads to corrosion of the metal with negative electrical potential, for example connection of piping made of galvanized steel after components containing copper results in corrosion on the galvanized piping. Electrical potential difference in water piping system can also result from sedimentation of various corrosion particles or other polluting particles in the piping, which can act as electrode, forming an electrochemical cell with the metal surface.

\footnotetext{
- Ivana Jeleníková, Jana Peráčková, Slovak University of Technology, Radlinského 11, 81368 Bratislava, Slovakia, ivana.jelenikova@gmail.com, jana.perackova@stuba.sk

Ondřej Šikula, Brno University of Technology, Veveři 331/95, Czech Republic, sikula.o@fce.vutbr.cz
} 
The transport of ions in the electrolyte is caused by:

1 - diffusion (movement caused by concentration gradient of particular ion)

2 - migration (movement caused by electrical potential gradient in the electrolyte)

3 - convection (movement caused by electrolyte flow)

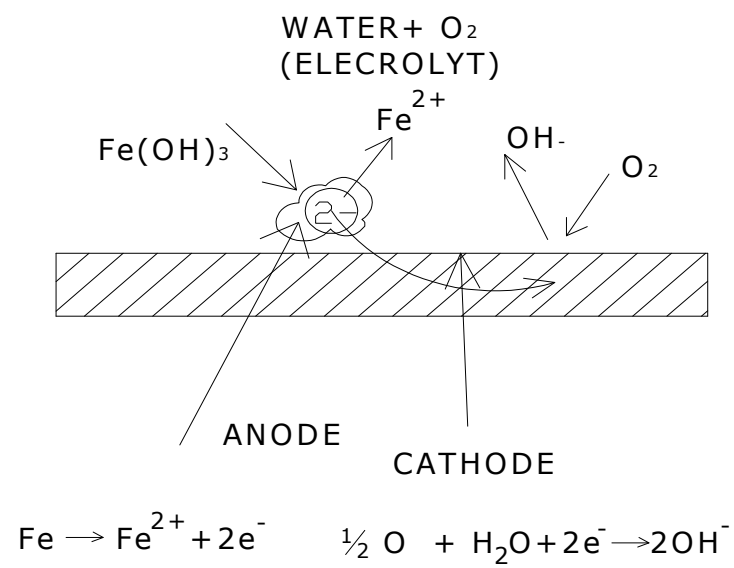

Figure 1: The principle of corrosion of iron [8].

Fig. 1 illustrates redox reaction of iron in the electrolyte. The electrical charge is not equal throughout the metal surface, due to manufacture defects or presence of impurities. It can therefore become the cathode at one point and the anode at another point and a flow of electrons can be established between these two points.

Two electrons (2e-) are released from the iron surface in an electrolytic environment. These electrons are then used by the reduction of oxygen according to the equation:

$$
1 / 2 \mathrm{O}_{2}+\mathrm{H}_{2} \mathrm{O}+2 \mathrm{e}^{-} \rightarrow 2 \mathrm{OH}^{-}
$$

The resulting hydroxide anion reacts with the ferrous cations and ferrous hydroxide is formed:

$$
2 \mathrm{OH}^{-}+\mathrm{Fe}^{2+} \rightarrow \mathrm{Fe}(\mathrm{OH})_{2}
$$

Ferrous hydroxide is an unstable white crystalline substance, which oxidizes immediately:

$$
\mathrm{Fe}(\mathrm{OH})_{2}+\mathrm{O}_{2} \rightarrow \mathrm{Fe}(\mathrm{OH})_{3}+\mathrm{H}_{2} \mathrm{O}
$$

Ferric oxide is thereby created, being a brown water-insoluble substance - rust [8].

Pitting corrosion occurs in water distributions systems under a deposition of water calc and water-insoluble substances or under a deposition of microbial origin, mostly in the water circulation piping, where the water velocity is low.

Causes of pitting corrosion are:

- formation of deposition on metallic materials of organic or inorganic origin (missing or faulty water treatment)

inappropriate choice of material

- failure to follow the required technological parameters of the system (low water flow rate - deposits formation)

a combination of these factors and water temperature (distribution of domestic hot water and circulation of domestic hot water).

After formation of the deposits it is difficult to prevent the corrosion under the deposits, because it is impossible to apply corrosion inhibitor on the metal surface [4]. 


\section{CFD Simulation and Experiments of Deposition of the CorRosion WASTE}

In Ansys Fluent was simulated water flow in the distribution system and deposition of the corrosion waste. The distribution system was designed so as taking into account problematic sections in the existing water distribution systems (Fig. 2) For a specific flow rate $3 \mathrm{l} / \mathrm{s}, 4 \mathrm{l} / \mathrm{s}$ and $5 \mathrm{l} / \mathrm{s}$. Simulating the water flow velocity, for chosen flow rates, were selected location with the lowest water flow rate. In these areas references particles deposition were simulated.In water distribution system which chemical reactions occur corrosive particles that settles and cause further corrosion. Was simulated water flow rate and particles deposition after formation the corrosion particles, and assume to by the particles chemically do not react.

In next step will simulation the chemical reaction in water distribution system.

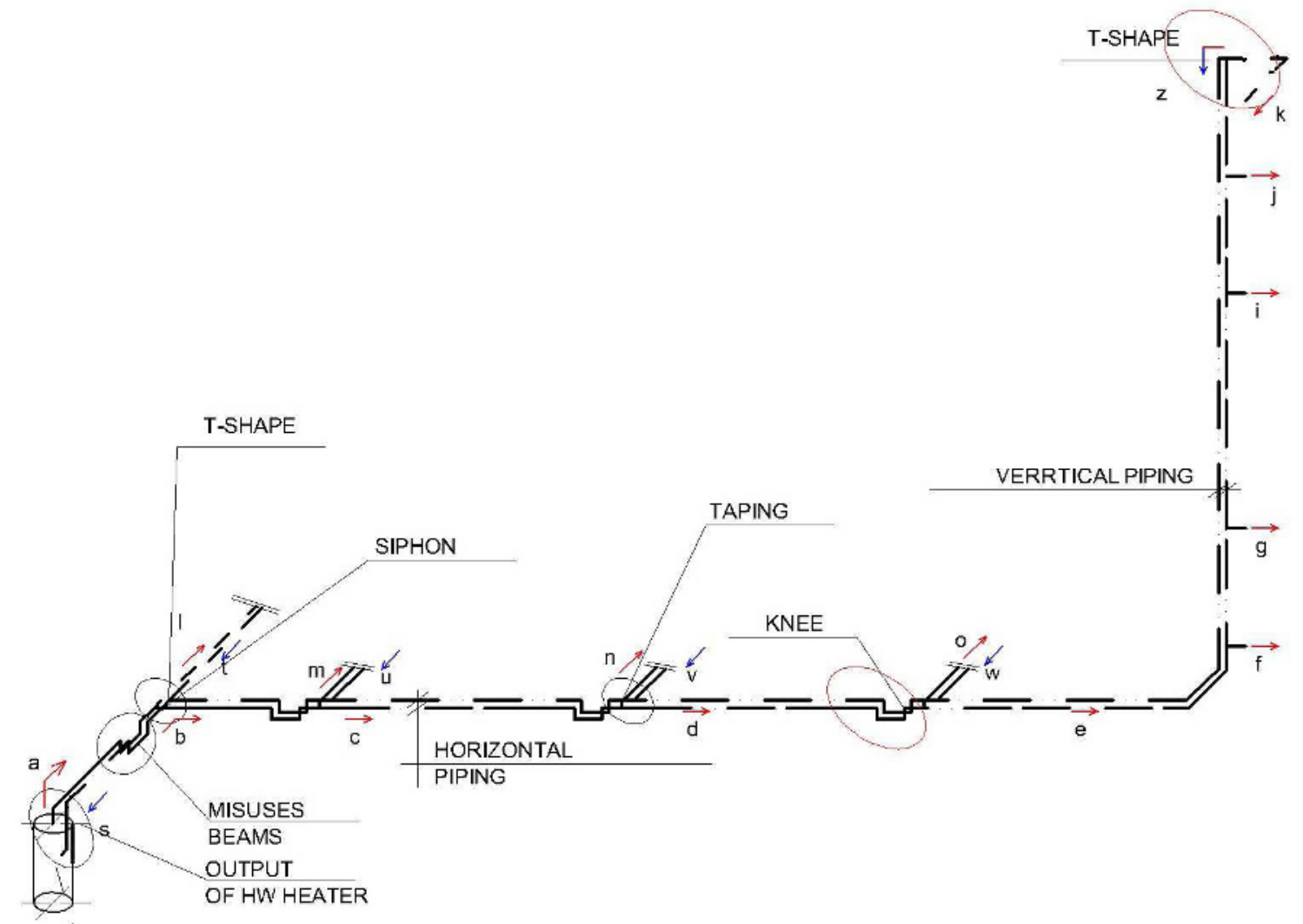

Figure 2: Scheme of selected sections of the aqueduct where the lowest rate of water flow, most likely to particle deposition.

The water flow in the distribution system and deposition the corrosion particles was simulated with discrete phase model. Trajectory of references particles and their concentration in the pipe surface were simulated. The trajectory of a discrete phase particle is written in a Lagrangian reference frame. The particles motion is described by equations (change of flow rate the reference particles in time):

$$
\frac{d u_{p}}{d t}=F_{D}\left(u-u_{p}\right)+\frac{g_{x}\left(\rho_{p}-\rho\right)}{\rho_{p}}+F_{x}
$$

where

$$
\begin{array}{ll}
F_{X} & \text { an additional acceleration term } \\
F_{D}\left(u-u_{p}\right) & \text { the drag force per unit particle mass and }
\end{array}
$$




$$
\begin{aligned}
& \qquad F_{D}=\frac{18 \mu}{\rho_{p} d_{p}^{2}} \frac{C_{D} \mathrm{Re}}{24} \\
& \text { where } \\
& \begin{array}{ll}
u & \text { fluid phase velocity, } \\
u_{p} & \text { particle velocity } \\
\mu & \text { them molecular viscosity of the fluid } \\
\rho & \text { fluid density } \\
d & \text { particle diameter }
\end{array}
\end{aligned}
$$

Re Reynolds number which is defined as

$$
\operatorname{Re}=\frac{\rho d_{p}\left(u_{p}-u\right)}{\mu}
$$

The water flow in the distribution piping was simulated for specific flow rates of $3 \mathrm{l} / \mathrm{s}$, $4 \mathrm{l} / \mathrm{s}$ and $5 \mathrm{l} / \mathrm{s}$. The simulation was done for selected segments of the distribution system with the lowest water flow velocity and thus with the highest risk of corrosion (Fig.2). In these segments deposition of reference particles was simulated, the reference particles being spheres with very small diameters. The piping was represented by the surface of a geometric scheme. The roughness of the simulated piping was zero. Bacterial microfilm is created on the inner surface of the piping and this microfilm is basically non-removable [3]. With regard to this fact, infinite reference particle adhesion was assumed in the simulation.

\section{Setting the discrete phase model}

Corrosion wastes were defined by reference particles. Discrete phase model to Number of Continuous Phase Iterations per DPM Iteration was set at 10 . Be set phase to five discrete fractions Injections, released from the surface of the water inlet. Material discrete phase was selected from database FLUENT, Calcium carbonate $\mathrm{CaCO}_{3}$, with a density and weight of default. Diameter of fraction are $1 \mu \mathrm{m}, 5$ micron, 20 micron, 80 micron, 100 micron fineness corresponding what used filters. Total flow rate the reference particle was calculated from the standard set a maximum amount of suspended solids in water $15 \mathrm{mg} / \mathrm{l}$. Total flow rate the reference particle was calculated from the standard sets amount of substances in water $15 \mathrm{mg} / \mathrm{l}$.

In fig. 3 are simulation results of velocity to the monitor areas T- shape and knee in the axis the pipe.

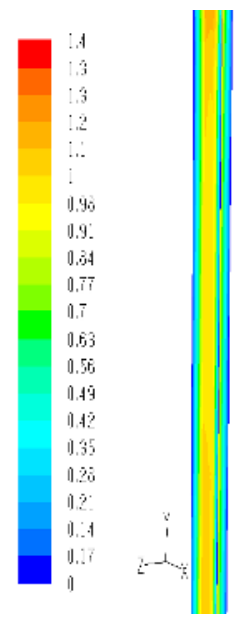

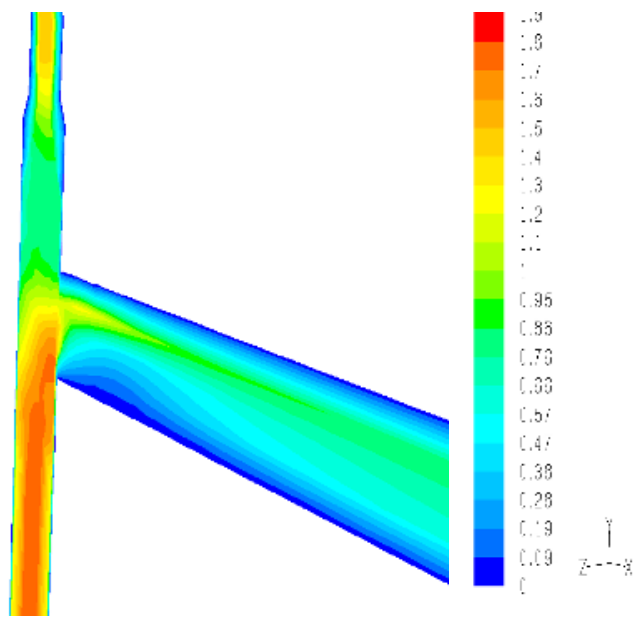

a)

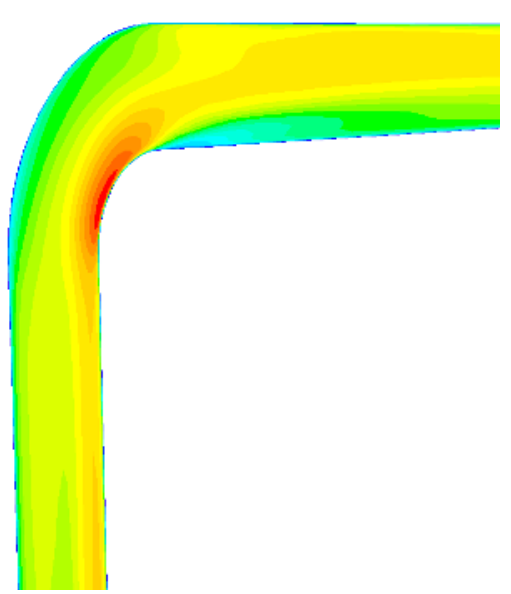

b)

Figure 3: The water flow velocity $(\mathrm{m} / \mathrm{s})$ a) T-Shape, b) knee. 
In fig. 4 are simulation results of deposition of the reference particles and a comparison with real deposits in water pipes. Steady-state particle concentrations on the pipe wall and in selected critical segments - T-piece - were simulated.

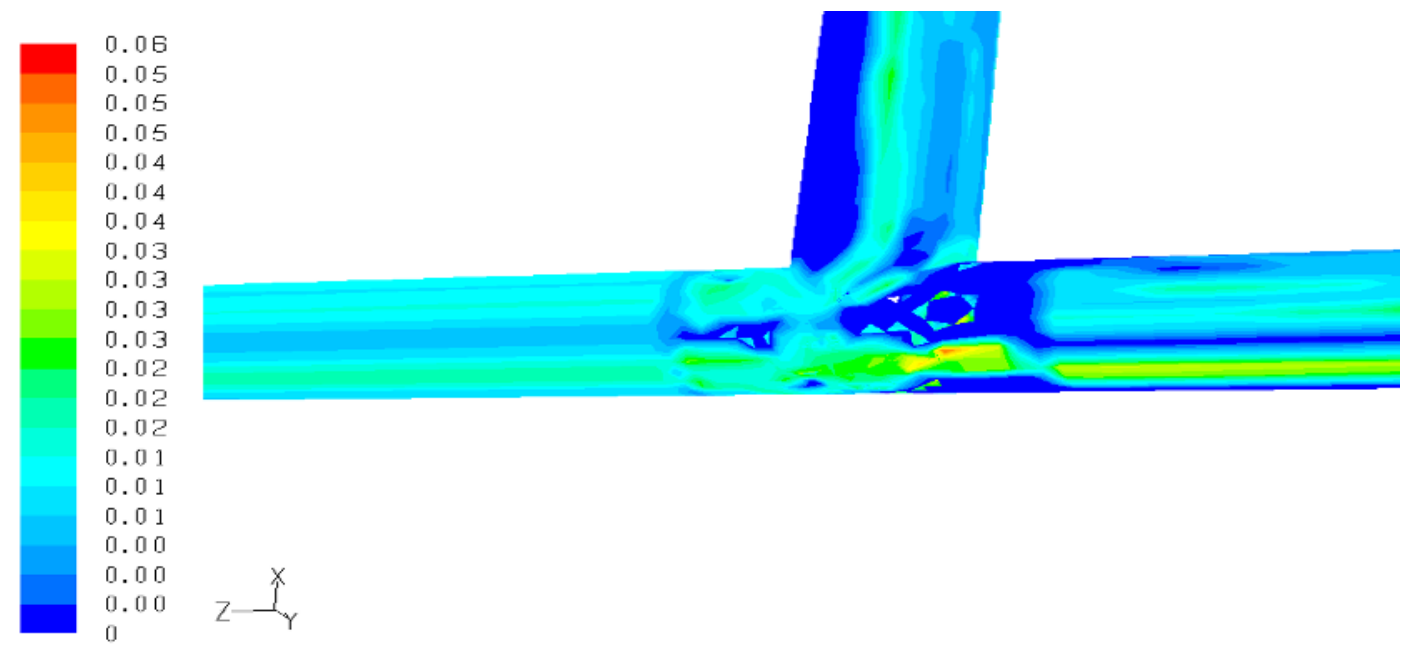

Figure 4: The concentration the corrosion waste in outdoor surface of the pipeline $(\mathrm{mg} / \mathrm{I})$

In figure 5 is the comparation the simulation and real corrosion in T-shape, in this figure we can see the corrosion in area who simulation shows the most concentration of reference particles.
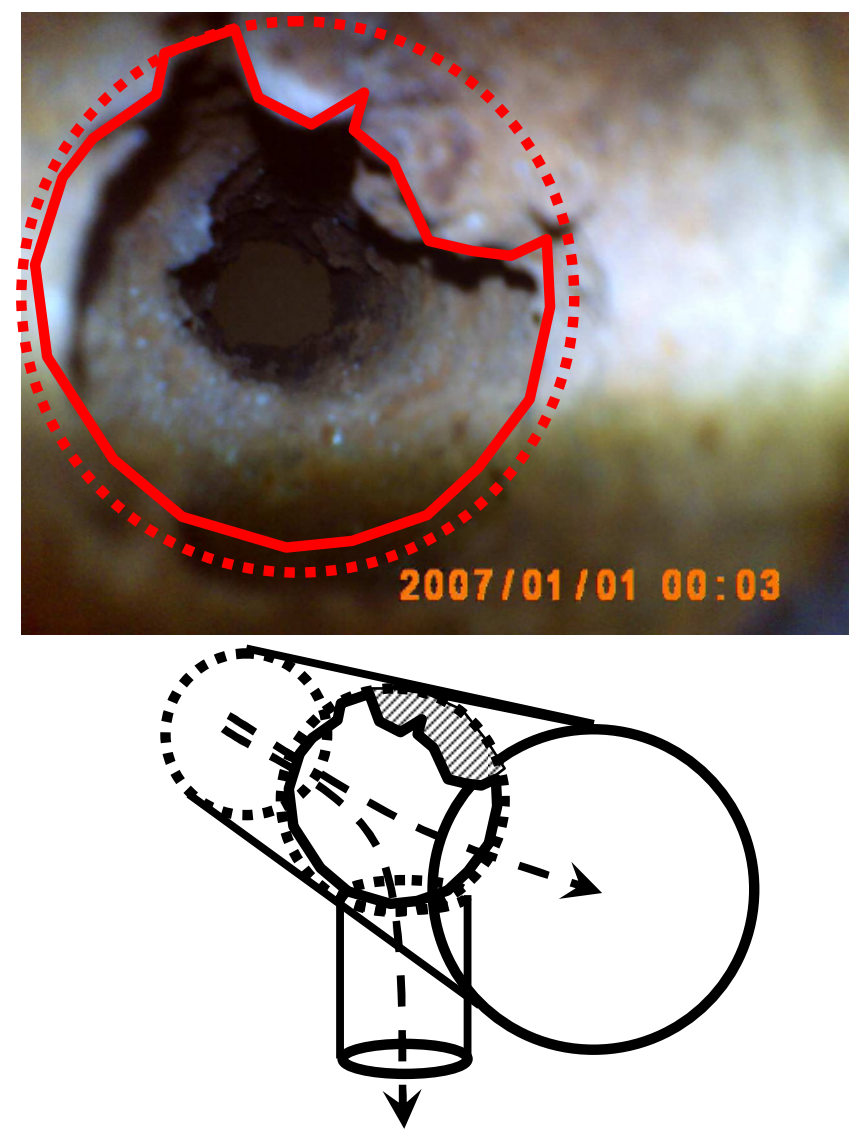

Figure 5: The galvanized steel piping the deposition the corrosion waste. 
In figure 6 is result of simulation the concentration of reference particles in knee.

a)

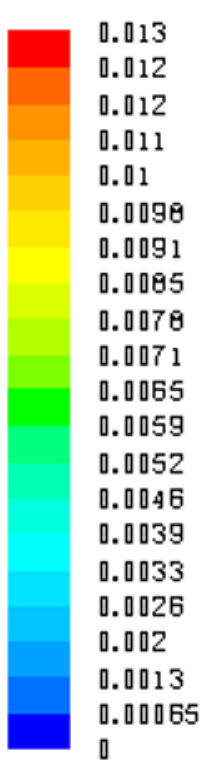

b)
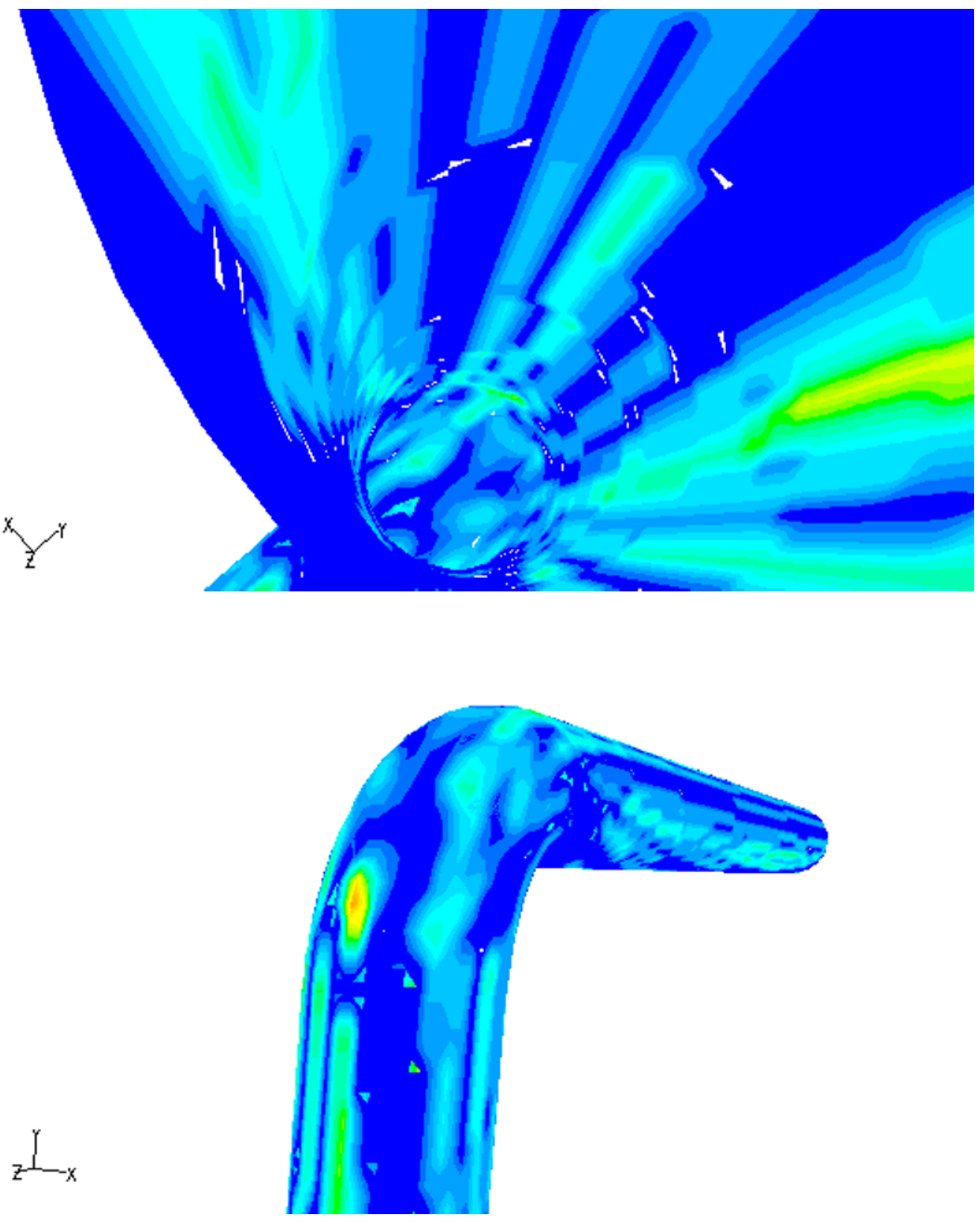

Figure 6: The concentration the references particles $(\mathrm{mg} / \mathrm{I})$ a) in the indoor surface the piping, b) in the outdoor surface. 

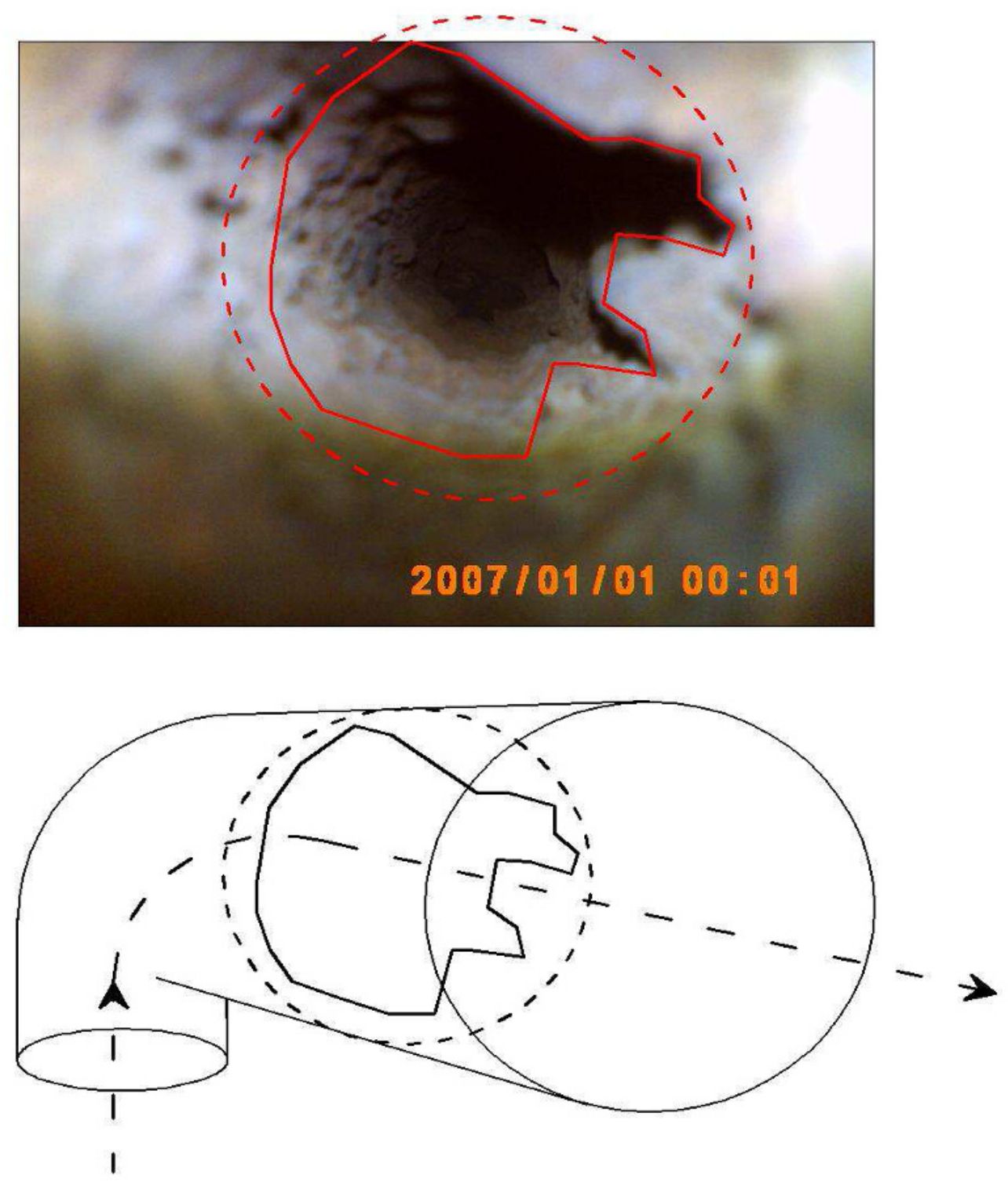

Figure 7: The galvanized steel piping the deposition the corrosion waste.

In figure 7 is the comparation the simulation and real corrosion in knee, in this figure we can see the corrosion in area who simulation shows the most concentration of reference particles.

\section{Conclusions}

The simulation verified the deposition of reference particles in the selected segments of the water piping. The risk of occurrence of the point corrosion is the greater, the greater the concentration of the deposited substances in the piping forming an electrochemical cell with the surface of the piping. The occurrence of point corrosion can be diminished by proper selection of the piping material, proper design of water velocity especially in the circulation domestic hot water piping, and proper realization of the system with installation of a fine particle filter. Installation of the filter is prescribed by BS EN 806-2, to prevent infiltration of dirt from public water line. In areas where pipeline is bypassing 
other structures it is necessary to install an outlet valve, which prevents deposition of the dirt in the piping.

\section{ACKNOWLedgment}

This contribution was prepared within the project VEGA $1 / 0511 / 11$. This paper originates also with a support of the Specific research at universities in the Czech Republic No.

FAST-S-11-1.

\section{References}

[1] Novák, P.: Základní princípy koroze kovů v elekrolytech, In: Korózia v energetike 2006, Košice. 2006. str. 1.

[2] Richardson, J.R. and Zaki, W. N.: Sedimentation and Fluidization, part 1, Tans. Inst. Chem Eng 3235531954

[3] Baldyga, J.: Turbulent mixer mode Iwith application to homogenous instantaneous chemical reactions. Chem.Eng.Sci.,44:11751182,1989. J.

[4] Lukáč, J., Vanovčan, J. Madej ,J.: Korózia pod nánosmi; Mechanizmy, Príčiny, Prevencia, In: Korózia v energetike 2008, Košice. 2008. str. 44

[5] Valášek, J.: Zdravotnotechnické zariadenia budov. Bratislava: Jaga. 2005

[6] Vranayová, Z.: Korózia a inkrustácia ocel'ového potrubia, In: Zborník SANHYGA, Pieštany. 1996. str.144.

[7] Ilavský, J., Barloková, D., Biskupič, F.: Chémia vody a hydrobiológia, STU, Bratislava, 2008

[8] Kocich, J., Tuleja, S.: Korózia a ochrana kovov, ALFA, Bratislava, 1988

[9] Košičanová, D.: Ochrana potrubí pred koróziou a inkrustáciou. In: Zborník SANHYGA, Piešt́any 1996. str.157.

[10] STN EN 10240 Vnútorné a/alebo vonkajšie ochranné povlaky na ocelových rúrach. Požiadavky na povlaky nanášané žiarovým zinkovaním ponorom $\checkmark$ automatizovaných prevádzkach.

[11] STN EN 806-2 Technické podmienky na zhotovovanie vodovodných potrubí na pitnú vodu vnútri budov. Čast́ 2: Navrhovanie 